\begin{tabular}{|c|c|c|}
\hline & Int.J.Curr.Microbiol.App.Sci (2021) 10(12): 322-333 & \\
\hline & $\begin{array}{l}\text { International Journal of Current Microbiology and Applied Sciences } \\
\text { ISSN: 2319-7706 Volume } 10 \text { Number } \mathbf{1 2} \mathbf{( 2 0 2 1 )} \\
\text { Journal homepage: http://www.ijcmas.com }\end{array}$ & $\$ 0$ \\
\hline $\begin{array}{l}\text { EXCELLENT } \\
\text { PUBLISHERS }\end{array}$ & & \\
\hline
\end{tabular}

\title{
Assessment of Genetic Variability, Heritability and Genetic Advance in Tomato
}

\author{
Santosh Kumari* and Sumit Patil \\ Department of Vegetable Science, Dr Y S Parmar University of Horticulture and Forestry, \\ Nauni, Solan, HP-173 230, HP, India \\ *Corresponding author
}

\begin{tabular}{|l|}
\hline Ke y w o r d s \\
Variability, \\
coefficients of \\
variation, \\
heritability, genetic \\
gain and tomato
\end{tabular}

\section{A B S T R A C T}

Tomato is an important plant grown in tropics as a perennial plant and in other areas mostly as annual plant. Tomato plant grows upto an height of 9 feet. The flowers are small, yellow and have five lobes on corolla. The fruit colour is green when unripe and red when it is fully ripe. Fruit is low in calorie and rich in vitamins and minerals. Genetic variability, heritability and genetic advance were assessed in thirty five genotypes of tomato at Departmental Research Farm of Vegetable Science, UHF, Solan, HP during kharif season, 2016. The experiment was laid out in RCBD with three replications. Analysis of variance revealed highly significant differences among genotypes for all the characters under study. The PCV (Phenotypic coefficient of variation) and GCV (Genotypic coefficient of variation) were higher for fruits per cluster $(49.66 \%$ and $49.50 \%)$, fruits per plant $(46.28 \%$ and $46.11 \%)$, yield per plant (38.13\% and $38.04 \%)$ and average fruit weight (30.39\% and $30.29 \%)$. High GCV and PCV provide the possibility of improving and fixing the characters through selection breeding. High heritability along with high estimates of genetic gain were observed for number of fruits per cluster $(99.33 \%$ and $101.63 \%)$, number of fruits per plant $(99.28 \%$ and $94.66 \%)$, fruit yield per plant $(99.52 \%$ and $78.18 \%)$ and average fruit weight $(99.35 \%$ and $62.19 \%)$. High heritability and genetic gain suggest the possibility of improvement of traits by means of selection due to existence of additive gene effect. Selection for these above characters will be fruitful in improving fruit yield in tomato.

\section{Introduction}

Tomato crop is of immense importance, grown throughout the world. This vegetable belongs to family Solanaceae. The crop originated in Peru Ecuador Bolivia, South America. Fruits are consumed either fresh or cooked and used in various processed forms. It is self pollinated and easy for carrying out breeding programmes. In North Indian plains, due to high temperature and rains, the crop is not grown during summer and rainy seasons, thereby giving an opportunity for vegetable growers of Himachal Pradesh to fetch off 
season remunerative prices. Since the crop is grown during summer and rainy season in HP, so many diseases, insects and pests appear on the plants leading to fewer yields. Being an important vegetable crop in the state, there is a need to develop high yielding tomato varieties, having resistance or tolerance to diseases and insect pest and suitable to agro ecological conditions. For selecting promising genotypes from a population, proper knowledge about variability existing for various characters in the germplasm is essential. Wider the genetic variability in the qualitative and quantitative traits, better would be the chances of crop improvement through selection. Variability present in the population is assessed by phenotypic and genotypic coefficients of variation. Estimates of heritability alone are not sufficient for predicting the effect of selection and therefore the genetic advance/gain is also equally important (Hanson and Earle, 1956). Burton and De-Vane (1953) has suggested that genetic co-efficient of variability along with heritability estimates would give a reliable indication of expected amount of improvement through selection

\section{Materials and Methods}

The experiment was conducted at the Departmental experiment field of Vegetable Science, UHF, Solan, HP in Kharif, 2016. Germplasm consisted of thirty five genotypes viz., Punjab Sartaj, Punjab Ratta, DMT KRCCH-4, BCT-8, LO-2410, DMT KRCCH1, Punjab Gaurav, BCT-10, BCT-5, DMT KRCCH-3, UHF-553, Punjab Red Cherry, BCT-2, BCT-4, DMT KRCCH-6, DMT KRCCH-2, Solan Vajr, S-1001, EC-524082, EC-433607, EC-21132, EC-2997, EC-36293, EC-141827, EC-16788, EC-3526, EC-15998, UHF-571, EC-29414, UHF-95, UHF-90, BT10-10, Selection-12, Selection-87 and Solan Lalima (check). Seedlings were planted in a randomized complete block design with three replications in plot size of $1.8 \mathrm{~m} \times 1.8 \mathrm{~m}$. Twelve plants of each entry were transplanted in each replication at spacing of $90 \mathrm{~cm} \times 30$ $\mathrm{cm}$ in April, 2016 The characters studied during the present study were days to $50 \%$ flowering, days to maturity, plant height, fruits per cluster, fruits per plant, fruit weight, yield per plant and per hectare, fruit shape index, pericarp thickness, locules per fruit, harvest duration, total soluble solids and ascorbic acid. Phenotypic coefficient of variation (PCV) and Genetic coefficient of variation (GCV) were computed as per Burton and De Vane (1953), heritability in broad sense as suggested by Allard et al., (1960) and genetic gain as per Johanson et al., (1955).

\section{Results and Discussion}

The analysis of variance indicated highly significant differences among the genotypes for all the trait studied, which revealed the existence of sufficient variability in the germplasm. Different genotypes differed significantly with respect to number of days to $50 \%$ flowering. Days to $50 \%$ flowering varied from 24.67 to 35.67 (Table 1). Genotype Punjab Red Cherry (24.67) took minimum days to reach $50 \%$ flowering. UHF-95 (35.67) recorded maximum days for $50 \%$ flowering. Among all the genotypes under study, as many as eighteen genotypes have taken lesser number of days to $50 \%$ flowering than check variety Solan Lalima (32.67 days). Variability for this character was reported by Sharma et al., (2010), Mohamed et al., (2012), Ahirwar and Prashad (2013), Reddy et al., (2013) and Kumar (2014). Punjab Red Cherry took minimum days to attain marketable maturity (66.00 days). Comparison of genotypes for plant height revealed that different genotypes differed significantly for plant height. It ranged from 52.51 to $123.65 \mathrm{~cm}$. Maximum plant height was recorded in Solan Vajr $(123.65 \mathrm{~cm})$, which was statistically at par with EC-2997 $(121.33 \mathrm{~cm})$ and Solan Lalima 
(120.32 cm). Minimum plant height was recorded in DMT KRCCH-2 $(52.51 \mathrm{~cm})$. Two genotypes viz., EC-2997 $(121.33 \mathrm{~cm})$ and Solan Lalima $(120.32 \mathrm{~cm})$ resulted in more plant height than the check variety Solan Lalima $(124.32 \mathrm{~cm})$. Data recorded on number of fruits per cluster showed significant variation among genotypes. Its value ranged from 2.76 to 15.07 . Three genotypes resulted in more number of fruits per cluster than check variety Solan Lalima (5.00). Maximum number of fruits per cluster (15.07) were in Punjab Red Cherry. Genotypes DMT KRCCH-2 (2.76) and UHF-95 (2.76) bear minimum number of fruits per cluster. Variability with respect to this trait was reported by Kumar et al., (2013) and Reddy et al., (2013).

Data recorded on number of fruits per plant showed significant variation among genotypes. The number of fruits per plant ranged from 11.25 to 70.02 . Maximum number of fruits per plant (70.02) were in Punjab Red Cherry, which was statistically superior over all other genotypes and check variety. However, minimum numbers of fruits per plant were recorded in DMT KRCCH-1 (11.25). Check variety Solan Lalima recorded 26.37 fruits per plant. Considerable variability regarding this trait was in accordance with the findings of Buckseth et al., (2012), Khan and Samadia (2012), Kumar et al., (2013), Reddy et al., (2013) and Kumar (2014). Maximum average fruit weight $(84.00 \mathrm{~g})$ was observed in Punjab Sartaj, which was statistically superior than all other genotypes. Minimum value for average fruit weight was recorded in the genotype Punjab Red Cherry (10.53 g). Check variety Solan Lalima recorded average fruit weight of $65.00 \mathrm{~g}$. Twelve genotypes recorded more average fruit weight than check Solan Lalima. Wide genetic variation with respect to this character was also reported by Asati et al., (2008), Ara et al., (2009), Ghosh et al., (2010), Shashikanth et al., (2010), Khan and
Samadia (2012), Reddy et al., (2013), Kumar et al., (2013), Premalakshmi et al., (2014) and Sharma and Jaipaul (2014). Maximum fruit yield per plant was recorded in Punjab Sartaj $(1.59 \mathrm{~kg})$. Whereas, minimum fruit yield per plant was recorded in EC-36293 $(0.41 \mathrm{~kg})$. Check variety Solan Lalima recorded $1.54 \mathrm{~kg}$ fruit yield per plant. Similarly, observation on yield per hectare showed that maximum yield per hectare was recorded by Punjab Sartaj (471.11 q/ha). Whereas, minimum yield per hectare was observed in genotype EC-36293 (121.48 q/ha) Check variety Solan Lalima recorded yield per hectare of about 456.29 q. Wide variation with respect to this character was recorded by Asati et al., (2008), Ara et al., (2009), Ghosh et al., (2010), Shashikanth et al., (2010), Khan and Samadia (2012), Reddy et al., (2013), Kumar et al., (2013), Singh et al., (2014), Premalakshmi et al., (2014) and Kumar (2014).

Significant differences were observed for fruit shape index. The mean performance of genotypes showed maximum fruit shape index value in DMT KRCCH-1 (1.19), which was statistically at par with DMT KRCCH-4 (1.17) and BT-10-10 (1.13) whereas, minimum value was observed in DMT KRCCH-6 (0.79). Index values for all the genotypes have been presented in table 2. Seven genotypes were found to have oval shape with an index value one and above, while twenty four genotypes fall under spherical group and four under flat round group. Similarly, tomato genotypes were also classified into oval, spherical and flat round categories by Buckseth et al., (2012), Kumar (2014) and Kharshandi (2015) as per the method suggested by Roy and Choudhary (1972). Pericarp thickness varied from 2.12 to $6.13 \mathrm{~mm}$. Six genotypes had more pericarp thickness than the check variety Solan Lalima $(5.20 \mathrm{~mm})$. Maximum pericarp thickness $(6.13 \mathrm{~mm})$ was observed in S-1001. Whereas, minimum pericarp thickness $(2.12$ $\mathrm{mm}$ ) was recorded in Punjab Red Cherry. The 
mean values of different genotypes for number of locules per fruit revealed that EC-29414 (2.50) and UHF-90 (2.50) had the lowest number of locules per fruit, which was statistically at par with fourteen genotypes viz., Punjab Red Cherry (2.53), EC-524082 (2.69), BCT-5 (2.73), UHF-571 (2.80), BCT10 (2.87), Solan Vajr (2.92), BCT-2 (2.93), S1001 (2.93), check variety Solan Lalima (2.99), EC-21132 (3.00), BT-10-10 (3.03), EC-2997 (3.07), Selection-87 (3.20) and BCT8 (3.20). Maximum number of locules per fruit were recorded in UHF-553 (5.00) Variation with respect to this character was reported by Joshi et al., (2004), Manna and Paul (2012), Buckseth et al., (2012) and Kumar (2014). Total soluble solids ranged from 3.27 to $6.32{ }^{0} \mathrm{~B}$. Seventeen genotypes recorded maximum value for total soluble solids than population mean. Maximum total soluble solids $\left(6.32{ }^{0} \mathrm{~B}\right)$ were recorded in EC21132, which was statistically at par with EC$16788\left(5.54{ }^{0} \mathrm{~B}\right), \mathrm{EC}-36293\left(5.71^{0} \mathrm{~B}\right)$, EC$141827\left(5.93{ }^{0} \mathrm{~B}\right), \mathrm{EC}-433607\left(5.97^{0} \mathrm{~B}\right)$ and Punjab Red Cherry $\left(6.04{ }^{0} \mathrm{~B}\right)$. Minimum total soluble solids $\left(3.27^{0} \mathrm{~B}\right)$ were observed in DMT KRCCH-3. Twelve genotypes recorded maximum value for total soluble solids than the check variety Solan Lalima $\left(4.94{ }^{0} \mathrm{~B}\right)$. Considerable variability regarding this trait was in accordance with the findings of Buckseth et al., (2012) and Kumar (2014).

Ascorbic acid content showed significant differences among the genotypes and ranged from 14.49 to $36.55 \mathrm{mg} / 100 \mathrm{~g}$. Genotype DMT KRCCH-2 had maximum ascorbic acid content (36.55 $\mathrm{mg} / 100 \mathrm{~g})$ which was statistically at par with DMT KRCCH-1 (35.39 mg/100 g), EC-524082 (36.32 mg/100 g) and DMT KRCCH-6 (36.51 mg/100 g). Minimum value for this trait was found in UHF-95 (14.49 mg/100 g). Nineteen genotypes recorded maximum value for total soluble solids than the check variety Solan Lalima (25.60 mg/100 g). Considerable variability with respect to this trait was reported by Dar and Sharma (2011), Reddy et al., (2013) and Kumar (2014).

Harvest duration varied between 27.00 to 42.67. Maximum harvest duration (42.67 days) was recorded in genotype Solan Lalima, which was statistically at par with EC-2997 (42.00 days), EC-524082 (42.00 days), Punjab Gaurav (41.67 days) and BT-10-10 (41.67 days). Minimum harvest duration was recorded in DMT KRCCH-3 (27.00 days). Eighteen genotypes including check were found to had more harvest duration than population mean. Considerable variability regarding this trait was found and similar findings were observed by Ara et al., (2009), Sharma and Jaipaul (2014), Kumar (2014) and Rai et al., (2016).

\section{Parameters of variability}

The parameters of variability viz., mean, range, coefficients of variation (genotypic and phenotypic), heritability (broad sense), genetic advance and genetic gain were worked out for various characters and are presented in table 2 .

\section{Coefficients of variation}

For all the characters studied, PCV (Phenotypic coefficient of variation) was higher in magnitude than the corresponding GCV (Genotypic coefficient of variation), though the difference was less in majority of cases thus, indicating that environmental factors have played less influence on the expression of these characters.

The investigation showed marked extent of variation for all the characters studied. The PCV and GCV were higher for fruits per cluster $(49.66 \%$ and $49.50 \%)$, fruits per plant (46.28 \% and $46.11 \%$ ), yield per plant (38.13 $\%$ and $38.04 \%$ ) and average fruit weight (30.39\% and $30.29 \%)$. Ghosh et al., (2010) 
and Kumar et al., (2013) reported high PCV and GCV for average fruit weight, fruits per cluster and fruits per plant. High PCV and GCV were reported for yield per plant and fruits per plant by Shashikanth et al., (2010).

Similarly high amount of PCV and GCV for average fruit weight, fruits per plant and yield per plant was observed by Khan and Samadia (2012). High PCV and GCV were also reported by Singh and Singh (2019) for fruits per plant, fruits per cluster, average fruit weight, yield per plant and per hectare. High PCV and GCV were recorded for yield per plant and fruit weight by Basfore et al., (2020).

Moderate phenotypic and genotypic coefficients of variation were observed for plant height $(24.38 \%$ and $24.26 \%)$, total soluble solids $(21.73 \%$ and $21.59 \%)$, number of locules (20.28\% and $20.11 \%$ ), fruit shape index (19.84\% and $19.69 \%)$ and pericarp thickness $(16.90 \%$ and $16.70 \%)$. For plant height, moderate phenotypic and genotypic coefficients of variation were reported by Reddy et al., (2013) and Singh and Singh (2019). Patel et al., (2013) reported moderate phenotypic and genotypic coefficients of variation for total soluble solids and locules per fruit. Dar et al., (2012) recorded moderate phenotypic and genotypic coefficients of variation for characters like pericarp thickness and number of locules per fruit. Kumar et al., (2012) and Basfore et al., (2020) also reported moderate phenotypic and genotypic coefficient of variation for total soluble solids and pericarp thickness. Low values of phenotypic and genotypic coefficient of variation were observed for ascorbic acid (13.65\% and $13.43 \%$ ), harvest duration (9.66 $\%$ and $9.33 \%$ ), days to $50 \%$ flowering (6.15 $\%$ and $5.65 \%$ ) and days to marketable maturity (5.91\% and $5.38 \%$ ). Reddy et al., (2013) reported low PCV and GCV for harvest duration, days to $50 \%$ flowering and days to maturity. Similarly low amount of PCV and GCV for harvest duration and days to marketable maturity were also observed by Ara et al., (2009) and Patel et al., (2013). Kumar (2014), Singh et al., (2015) and Singh and Singh (2019) reported low phenotypic and genotypic coefficients of variation for days to $50 \%$ flowering.

\section{Heritability}

Heritability (broad sense) estimates ranged from 82.99 percent to 99.52 percent. High heritability was recorded for fruit yield per plant (99.52\%), average fruit weight $(99.35$ $\%)$, number of fruits per cluster (99.33\%), number of fruits per plant (99.22\%), harvest duration (98.96\%), total soluble solids (98.73 $\%)$, fruit shape index $(98.50 \%)$, number of locules per fruit $(98.33 \%)$, plant height (97.93 $\%)$, pericarp thickness $(97.71 \%)$, ascorbic acid $(96.72 \%)$, days to $50 \%$ flowering (84.40 $\%)$ and days to marketable maturity (82.99 $\%)$. High heritability estimates for the characters number of fruits per plant, number of fruits per cluster and pericarp thickness were reported by Kumar et al., (2012). Khan and Samadia (2012) observed high heritability estimates for the characters fruit yield per plant and plant height. Similar results to present study were also reported by Premalakshmi et al., (2014) and Rai et al., (2016) who recorded high heritability for number of fruits per plant and average fruit weight. Meena and Bahudur (2014) and Hasan et al., (2016) noted high heritability estimates for plant height, days to $50 \%$ flowering, fruits per plant, average fruit weight, yield per plant, harvest duration, total soluble solids and ascorbic acid. Singh and Singh (2019) recorded high heritability for fruits per plant, fruits per cluster, average fruit weight and yield per plant. Basfore et al., (2020) observed high heritability for plant height, fruit weight, pericarp thickness, locule number and yield per plant. 
Table.1 Mean performance of tomato genotypes for various characters

\begin{tabular}{|c|c|c|c|c|c|c|c|c|c|c|c|c|c|c|}
\hline Genotypes & $\begin{array}{c}\text { Days to } \\
50 \% \\
\text { flowerings }\end{array}$ & $\begin{array}{c}\text { Days } \\
\text { to } \\
\text { marketable } \\
\text { maturity }\end{array}$ & $\begin{array}{c}\text { Plant } \\
\text { height } \\
(\mathrm{cm})\end{array}$ & $\begin{array}{c}\text { Numbers } \\
\text { of } \\
\text { fruits } \\
\text { per cluster }\end{array}$ & $\begin{array}{l}\text { Numbers } \\
\text { of fruits } \\
\text { per plant }\end{array}$ & $\begin{array}{l}\text { Average } \\
\text { fruit } \\
\text { weight (g) }\end{array}$ & $\begin{array}{l}\text { Yield } \\
\text { per } \\
\text { plant } \\
(\mathbf{k g})\end{array}$ & $\begin{array}{c}\text { Yield } \\
\text { per } \\
\text { hectar } \\
\text { e (q) }\end{array}$ & $\begin{array}{l}\text { Fruit } \\
\text { Shape } \\
\text { index }\end{array}$ & $\begin{array}{c}\text { Pericarp } \\
\text { thickness } \\
(\mathbf{m m})\end{array}$ & $\begin{array}{c}\text { Numbe } \\
\text { r of } \\
\text { locules } \\
\text { per } \\
\text { fruit }\end{array}$ & $\begin{array}{c}\text { Total } \\
\text { solubl } \\
\text { e } \\
\text { solids } \\
\left({ }^{0} \mathrm{~B}\right)\end{array}$ & $\begin{array}{c}\text { Ascorbi } \\
\text { c acid } \\
(\mathrm{mg} / 100 \\
\text { g) }\end{array}$ & $\begin{array}{c}\text { Harvest } \\
\text { duratio } \\
\text { n (days) }\end{array}$ \\
\hline $\begin{array}{c}\text { Punjab } \\
\text { Sartaj }\end{array}$ & 31.67 & 74.67 & $\begin{array}{c}107.4 \\
4\end{array}$ & 4.92 & 22.80 & 84.00 & 1.59 & 471.11 & 0.98 & 4.48 & 3.47 & 3.32 & 23.74 & 40.33 \\
\hline Punjab Ratta & 31.00 & 73.67 & 75.33 & 5.30 & 23.27 & 62.73 & 1.42 & 420.74 & 1.03 & 5.22 & 3.33 & 3.77 & 33.18 & 39.67 \\
\hline $\begin{array}{c}\text { DMT } \\
\text { KRCCH-4 }\end{array}$ & 33.33 & 79.00 & 69.01 & 3.70 & 14.80 & 69.07 & 1.02 & 302.22 & 1.17 & 4.54 & 3.47 & 3.31 & 31.63 & 28.67 \\
\hline ВCT-8 & 32.67 & 70.00 & 69.88 & 4.80 & 14.50 & 75.80 & 1.09 & 322.96 & 0.88 & 5.30 & 3.20 & 3.66 & 29.29 & 29.67 \\
\hline LO-2410 & 32.00 & 71.67 & $\begin{array}{c}112.3 \\
9\end{array}$ & 3.10 & 18.60 & 42.53 & 0.62 & 183.70 & 0.89 & 4.08 & 3.93 & 4.53 & 33.03 & 35.33 \\
\hline $\begin{array}{c}\text { DMT } \\
\text { KRCCH-1 }\end{array}$ & 31.67 & 75.00 & 64.41 & 3.00 & 11.25 & 62.53 & 0.48 & 142.22 & 1.19 & 4.28 & 3.40 & 3.52 & 35.39 & 29.67 \\
\hline $\begin{array}{l}\text { Punjab } \\
\text { Gaurav }\end{array}$ & 31.67 & 80.33 & $\begin{array}{c}105.1 \\
3\end{array}$ & 5.27 & 21.88 & 75.67 & 1.53 & 453.33 & 0.99 & 5.45 & 3.53 & 3.49 & 21.48 & 41.67 \\
\hline BCT-10 & 32.00 & 75.33 & 60.53 & 4.99 & 12.72 & 78.80 & 1.00 & 296.30 & 0.89 & 4.16 & 2.87 & 4.97 & 29.99 & 31.33 \\
\hline BCT-5 & 31.33 & 77.67 & 55.00 & 3.74 & 13.25 & 74.73 & 0.98 & 290.37 & 0.96 & 4.53 & 2.73 & 4.21 & 29.84 & 27.67 \\
\hline $\begin{array}{c}\text { DMT } \\
\text { KRCCH-3 }\end{array}$ & 32.00 & 78.00 & 58.93 & 4.49 & 15.00 & 62.53 & 0.93 & 275.55 & 0.93 & 4.20 & 3.80 & 3.27 & 18.62 & 27.00 \\
\hline UHF-553 & 33.00 & 67.00 & 93.15 & 3.84 & 23.80 & 65.00 & 1.20 & 355.55 & 0.91 & 4.50 & 5.00 & 4.44 & 26.58 & 37.00 \\
\hline $\begin{array}{c}\text { Punjab Red } \\
\text { Cherry }\end{array}$ & 24.67 & 66.00 & 85.45 & 15.07 & 70.02 & 10.53 & 0.70 & 207.40 & 1.03 & 2.12 & 2.53 & 6.04 & 28.42 & 28.33 \\
\hline BCT-2 & 32.67 & 68.00 & 71.67 & 3.80 & 14.20 & 70.00 & 0.99 & 293.33 & 0.94 & 4.52 & 2.93 & 3.74 & 23.52 & 31.00 \\
\hline ВCT-4 & 31.67 & 75.33 & 65.98 & 3.72 & 13.50 & 74.20 & 1.00 & 296.29 & 0.99 & 5.32 & 3.47 & 3.31 & 26.55 & 36.00 \\
\hline $\begin{array}{c}\text { DMT } \\
\text { KRCCH-6 }\end{array}$ & 33.00 & 77.33 & 73.95 & 3.16 & 14.00 & 63.93 & 0.83 & 245.92 & 0.79 & 3.54 & 3.93 & 3.53 & 36.51 & 35.33 \\
\hline $\begin{array}{c}\text { DMT } \\
\text { KRCCH-2 }\end{array}$ & 31.67 & 76.33 & 52.51 & 2.76 & 13.20 & 73.93 & 0.73 & 216.29 & 0.82 & 5.46 & 3.87 & 3.41 & 36.55 & 28.33 \\
\hline Solan Vajr & 32.33 & 80.00 & $\begin{array}{c}123.6 \\
5\end{array}$ & 4.16 & 21.83 & 71.00 & 1.23 & 364.44 & 0.96 & 5.18 & 2.92 & 3.67 & 24.88 & 39.67 \\
\hline S-1001 & 29.67 & 77.00 & 75.90 & 4.28 & 22.33 & 70.15 & 1.32 & 391.11 & 1.02 & 6.13 & 2.93 & 3.89 & 29.67 & 36.67 \\
\hline EC-524082 & 34.67 & 72.67 & $\begin{array}{c}116.7 \\
8\end{array}$ & 3.97 & 23.07 & 37.67 & 0.87 & 257.77 & 0.96 & 3.24 & 2.69 & 4.35 & 36.32 & 42.00 \\
\hline EC-433607 & 32.67 & 70.33 & 117.2 & 4.20 & 20.00 & 38.73 & 0.77 & 228.14 & 0.98 & 3.67 & 4.00 & 5.97 & 26.65 & 40.00 \\
\hline
\end{tabular}




\begin{tabular}{|c|c|c|c|c|c|c|c|c|c|c|c|c|c|c|}
\hline & & & 4 & & & & & & & & & & & \\
\hline EC-21132 & 29.00 & 69.00 & 76.04 & 3.56 & 18.51 & 43.00 & 0.60 & 177.77 & 0.85 & 3.37 & 3.00 & 6.32 & 25.16 & 35.33 \\
\hline EC-2997 & 31.67 & 68.67 & $\begin{array}{c}121.3 \\
3\end{array}$ & 3.99 & 21.57 & 57.01 & 0.93 & 275.55 & 0.91 & 3.98 & 3.07 & 4.95 & 19.77 & 42.00 \\
\hline EC-36293 & 33.00 & 70.00 & 64.61 & 2.79 & 16.33 & 42.60 & 0.41 & 121.48 & 0.98 & 4.54 & 4.03 & 5.71 & 33.21 & 32.00 \\
\hline EC-16788 & 32.67 & 72.67 & 77.05 & 3.41 & 18.00 & 43.57 & 0.48 & 142.22 & 0.90 & 3.63 & 4.40 & 5.54 & 23.49 & 32.00 \\
\hline EC-3526 & 34.33 & 68.67 & 94.78 & 3.24 & 19.39 & 34.63 & 0.65 & 192.59 & 0.87 & 3.10 & 3.67 & 4.84 & 26.43 & 39.00 \\
\hline EC-15998 & 35.00 & 70.67 & $\begin{array}{c}114.0 \\
9\end{array}$ & 4.03 & 20.94 & 66.50 & 0.84 & 248.88 & 0.93 & 4.18 & 3.73 & 4.43 & 19.83 & 39.67 \\
\hline EC-29414 & 32.67 & 72.00 & 84.35 & 2.83 & 17.34 & 36.08 & 0.44 & 130.37 & 1.02 & 3.37 & 2.50 & 5.19 & 28.49 & 35.33 \\
\hline UHF-95 & 35.67 & 67.67 & 84.82 & 2.76 & 16.40 & 37.09 & 0.43 & 127.40 & 0.87 & 3.59 & 3.47 & 4.40 & 14.49 & 33.33 \\
\hline UHF-90 & 34.33 & 70.33 & 85.09 & 2.97 & 18.30 & 31.13 & 0.53 & 157.03 & 0.98 & 3.34 & 2.50 & 5.33 & 16.50 & 38.33 \\
\hline BT-10-10 & 32.00 & 67.67 & $\begin{array}{c}109.9 \\
9\end{array}$ & 4.51 & 24.53 & 45.58 & 1.11 & 328.88 & 1.13 & 4.54 & 3.03 & 4.68 & 23.47 & 41.67 \\
\hline Selection-12 & 33.67 & 74.33 & $\begin{array}{c}104.1 \\
4\end{array}$ & 3.40 & 23.80 & 45.74 & 1.08 & 320.00 & 0.87 & 4.31 & 3.37 & 5.12 & 24.85 & 40.33 \\
\hline Selection-87 & 32.67 & 79.67 & $\begin{array}{c}107.2 \\
0\end{array}$ & 3.49 & 24.13 & 51.00 & 1.22 & 361.48 & 0.86 & 4.25 & 3.20 & 4.65 & 26.49 & 39.00 \\
\hline $\begin{array}{l}\text { Solan Lalima } \\
\text { (check) }\end{array}$ & 32.67 & 73.33 & $\begin{array}{c}120.3 \\
2\end{array}$ & 5.00 & 26.37 & 65.00 & 1.54 & 456.29 & 0.94 & 5.20 & 2.99 & 4.94 & 25.60 & 42.67 \\
\hline Mean & 32.24 & 73.02 & 88.13 & 4.12 & 20.27 & 56.17 & 0.91 & 271.00 & 0.95 & 4.25 & 3.35 & 4.50 & 26.60 & 35.60 \\
\hline $\mathbf{C D}_{(0.05)}$ & 2.62 & 4.77 & 3.57 & 0.27 & 1.32 & 2.42 & 0.04 & 11.90 & 0.10 & 0.50 & 0.79 & 0.83 & 1.84 & 1.43 \\
\hline
\end{tabular}

Table.2 Categories of genotypes on the basis of fruit shape index values

\begin{tabular}{|c|c|c|}
\hline $\begin{array}{l}\text { Fruit shape } \\
\text { index values }\end{array}$ & Shapes & Genotypes \\
\hline 1 or more & Oval & $\begin{array}{l}\text { Punjab Ratta, DMT KRCCH-4, DMT KRCCH-1, Punjab Red Cherry, } \\
\text { S-1001, EC-29414, BT-10-10 }\end{array}$ \\
\hline 0.86-0.99 & Spherical & $\begin{array}{c}\text { Punjab Sartaj, BCT-8, LO-2410, Punjab Gaurav, BCT-10, BCT-5, } \\
\text { DMT KRCCH-3, UHF-553, BCT-2, BCT-4, Solan Vajr, EC-524082, } \\
\text { EC-433607, EC-2997, EC-36293, EC-141827, EC-16788, EC-3526, } \\
\text { EC-15998, UHF-571, UHF-95, UHF-90, Selection-12, Solan Lalima } \\
\text { (check) }\end{array}$ \\
\hline 0.71-0.85 & Flat round & DMT KRCCH-6, DMT KRCCH-2, EC-21132, Selection-87 \\
\hline
\end{tabular}


Table.3 Estimation of phenotypic and genotypic coefficients of variation, heritability, genetic advance and genetic gain for various traits in tomato

\begin{tabular}{|c|c|c|c|c|c|c|c|c|}
\hline \multirow[t]{2}{*}{ Characters } & \multirow[t]{2}{*}{ Mean } & \multicolumn{2}{|c|}{ Range } & \multicolumn{2}{|c|}{$\begin{array}{l}\text { Coefficient of variability } \\
(\%)\end{array}$} & \multirow{2}{*}{$\begin{array}{c}\text { Heritability } \\
\text { (Broad } \\
\text { sense) }(\%)\end{array}$} & \multirow[t]{2}{*}{$\begin{array}{l}\text { Genetic } \\
\text { advance }\end{array}$} & \multirow{2}{*}{$\begin{array}{c}\text { Genetic } \\
\text { gain } \\
(\%)\end{array}$} \\
\hline & & Minimum & Maximum & Phenotypic & Genotypic & & & \\
\hline Days to $50 \%$ flowerings & 32.24 & 24.67 & 35.67 & 6.15 & 5.65 & 84.40 & 3.45 & 10.70 \\
\hline Days to marketable maturity & 73.02 & 66.00 & 80.33 & 5.91 & 5.38 & 82.99 & 7.37 & 10.10 \\
\hline Plant height $(\mathrm{cm})$ & 88.13 & 52.51 & 123.65 & 24.38 & 24.26 & 98.96 & 43.81 & 49.71 \\
\hline Numbers of fruits per cluster & 4.12 & 2.76 & 15.07 & 49.66 & 49.50 & 99.33 & 4.19 & 101.63 \\
\hline Numbers of fruits per plant & 20.39 & 11.25 & 70.02 & 46.28 & 46.11 & 99.28 & 19.56 & 94.66 \\
\hline Average fruit weight (g) & 56.17 & 10.53 & 84.00 & 30.39 & 30.29 & 99.35 & 34.93 & 62.19 \\
\hline Fruit yield/plant (Kg) & 0.92 & 0.41 & 1.61 & 38.13 & 38.04 & 99.52 & 0.72 & 78.18 \\
\hline Fruit shape index & 0.95 & 0.79 & 1.19 & 19.84 & 19.69 & 98.50 & 1.71 & 40.26 \\
\hline Pericarp thickness (mm) & 4.25 & 2.12 & 6.13 & 16.90 & 16.70 & 97.71 & 1.14 & 34.02 \\
\hline Number of locules per fruit & 3.35 & 2.50 & 5.00 & 20.28 & 20.11 & 98.33 & 1.85 & 41.09 \\
\hline Total soluble solids $\left({ }^{0} \mathbf{B}\right)$ & 4.50 & 3.27 & 6.32 & 21.73 & 21.59 & 98.73 & 11.76 & 44.21 \\
\hline Ascorbic acid (mg/100g) & 26.60 & 14.49 & 36.55 & 13.65 & 13.43 & 96.72 & 9.69 & 27.21 \\
\hline Harvest duration (days) & 35.60 & 27.00 & 42.67 & 9.66 & 9.33 & 93.37 & 0.17 & 18.58 \\
\hline
\end{tabular}




\section{Genetic advance and genetic gain}

The genetic gain (genetic advance expressed as per cent of population mean) was low to high in nature and ranged from 10.10 to 101.63 percent. High genetic gain was recorded for number of fruits per cluster $(101.63 \%)$, fruit yield per plant $(78.18 \%)$, number of fruits per plant $(94.66 \%)$ and average fruit weight $(62.19 \%)$. High genetic gain was recorded for number of fruits per cluster, average fruit weight, number of fruits per plant and fruit yield per plant was in accordance with the findings of Kumar et al., (2013), Basavaraj et al., (2015) and Singh and Singh (2019). Genetic gain was moderate for plant height $(49.71 \%)$, total soluble solids (44.21\%), number of locules per fruit (41.09 $\%)$, fruit shape index $(40.26 \%)$, pericarp thickness (34.02\%) and ascorbic acid (27.21 $\%)$. Moderate genetic gain for total soluble solids was observed by Reddy et al., (2013) and Basavaraj et al., (2015), for pericarp thickness, plant height and number of locules per fruit by Kingsley (2015) and for ascorbic acid by Reddy et al., (2013). Moderate genetic gain for plant height and days to $50 \%$ flowering were observed by Singh and Singh (2019). Low genetic gain was observed for harvest duration $(18.58 \%)$, days to $50 \%$ flowering $(10.70 \%)$ and days to marketable maturity $(10.10 \%)$. Low values of genetic gain for harvest duration were also observed by Ara et al., (2009) and Patel et al., (2013), for days to $50 \%$ flowering and days to marketable maturity by Mehta and Asati (2008), Patel et al., (2013) and Kumar et al., (2014).

High heritability along with high estimates of genetic gain were observed for number of fruits per cluster (99.33\% and $101.63 \%$ ), number of fruits per plant $(99.28 \%$ and 94.66 $\%)$, fruit yield per plant $(99.52 \%$ and 78.18 $\%)$ and average fruit weight $(99.35 \%$ and $62.19 \%$ ). Khan and Samadia (2012) reported high heritability along with high estimates of genetic gain for characters like number of fruits per plant and average fruit weight. Basavaraj et al., (2015) reported high heritability and high estimates of genetic gain for fruits per cluster and fruits per plant. Singh et al., (2015) and Rai et al., (2016) observed high heritability and high estimates of genetic gain for fruit yield per plant. High heritability along with high genetic gain for number of fruits per cluster, average fruit weight, number of fruits per plant and fruit yield per plant was in accordance with the findings of Singh and Singh (2019). Basfore et al., (2020) observed high genetic gain and high heritability for plant height, fruit weight, pericarp thickness, locule number and yield per plant. High heritability along with moderate genetic gain was observed for plant height $(98.96 \%$ and $49.71 \%)$, total soluble solids $(98.73 \%$ and $44.21 \%)$, number of locules per fruit $(98.33$ $\%$ and $41.09 \%)$, fruit shape index $(98.50 \%$ and $40.26 \%)$, pericarp thickness $(97.71 \%$ and $34.02 \%)$ and ascorbic acid (96.72\% and $27.21 \%)$. High heritability coupled with moderate genetic gain for pericarp thickness was noted by Kumar et al., (2013) and for ascorbic acid content by Reddy et al., (2013). Singh et al., (2015) observed high heritability and moderate genetic gain for total soluble solids and number of locules per fruit. Kumar et al., (2012) recorded high heritability and moderate gain for plant height, pericarp thickness and total soluble solids. High heritability along with low genetic gain was observed for harvest duration $(93.37 \%$ and $18.58 \%$ ), days to $50 \%$ flowering (84.40\% and $10.70 \%$ ) and days to marketable maturity $(82.99 \%$ and $10.10 \%)$.

\section{Acknowledgment}

Special thanks to Dr YS Parmar University of Horticulture and Forestry, Nauni, Solan (HP), India for providing necessary facilities to conduct the study. 


\section{References}

Ahirwar C S and Prashad V M (2013) Variability pattern in agromorphological characters in tomato genotypes (Lycopersicon esculentum Mill.). Trend. Biosci. 6:758-61.

Allard R W (1960) Principles of Plant Breeding, John Wiley and Sons, Inc. New York, pp 485

Ara Anjum, Narayan Raja, Ahmed Nazeer and Khan S H (2009) Genetic variability and selection parameters for yield and quality attributes in tomato. Ind. J. Hort. 66(1): 73-78

Asati B S, Rai N and Singh A K (2008) Genetic parameters study for yield and quality traits in tomato. Asian J. Hort. 3: 222-25.

Basavaraj L B, Vilas D G and Vijayakumar R (2015) Study on genetic variability and character inter-relationship of quality and yield components in tomato (Solanum lycopersicum L.). HortFlora Res. Spect. 4: 108-115.

Basfore Shibnath, Sikder Subhamoy, Das Bimal, Manjunath K V and Chatterjee Ranjit (2020) Genetic variability, character association and path coefficient studies in tomato (Solanum lycopersicum L.) gown under terai region of West Bengal. Int. J. Chem. Stu. 8(2):569-573.

Bora G C, Shadique A, Bora L C and Phookon A K (1993) Evaluation of some tomato genotypes for variability and bacterial wilt resistance. Veg. Sci. 20: 44-47.

Buckseth T, Sharma M K and Thakur K S (2012) Genetic variability and path analysis in tomato (Solanum lycopersicum L.). Veg. Sci. 39:221-23.

Burton G W and De Vane E H (1953) Estimating heritability in tall fescue (Festuca arundinacea) from replicated clonal material. Agron. J. 45: 478-81.
Dar R A and Sharma J P (2011) Genetic variability studies for yield and quality traits in tomato (Solanum lycopersicum L.). Int. J. Pl. Breed. Genet. 5:168-74.

Dar R A, Sharma J P, Gupta R K and Chopra S (2011) Studies on correlation and path analysis for yield and physiochemical traits in tomato (Lycopersicon esculentum Mill.). Vegetos-An Int. J. Pl. Res. 24:136-41.

Ghosh K P, Islam A K M A, Mian M A K and Hossain M M (2010) Variability and character association in $\mathrm{F}_{2}$ segregating population of different commercial hybrids of tomato (Solanum lycopersicum L.). J. App. Sci., Env. Manag. 14: 91 - 95.

Hanson L N and Earle E D. 1956. Transfer of resistance to Xanthomonas campestris pv. campestris into Brassica oleracea var. capitata L. by protoplast fusion. Theoretical Applied Genetics 91(8): 1293-1300

Hasan M M, Bari M A and Hossain M A (2016) Genetic variability and traits association analysis of tomato (Lycopersicon esculentum L.) genotypes for yield and quality attributes. Uni. J. Pl. Sci. 4: 23-34.

Haydar A, Mandal M A, Ahmed M B, Hannan M M, Karim R, Razuy M A, Roy K U and Salahin M (2007) Studies on genetic variability and interrelationship among the different traits in tomato (Lycopersicon esculentum Mill.). Middle-East J. Scient. Res. 2:139-42.

Johanson H W, Robinson H F and Comstock R E (1955). Estimates of genetic and environmental variability in soyabean. Agro. J. 47: 314-18

Joshi Arun, Vikram Amit and Thakur M C (2004) Studies on genetic variability, correlation and path analysis for yield and physio-chemical traits in tomato (Lycopersicon esculentum Mill.). Prog. Hort. 36:51-58. 
Khan H and Samadia D K (2012) Variability and association studies in tomato germplasm under high-temperature arid region. J. Hort. Sci. 7: 194-98

Khapte P S and Jansirani P (2014) Genetic variability and performance studies of tomato (Solanum lycopersicum L.) genotypes for fruit quality and yield. Trend. Biosci 7:1246-48.

Kharshandi G (2015) Studies on genetic evaluation of some tomato (Solanum lycopersicum L.) genotypes for yield and contributing traits, M.Sc. Thesis, Department of Vegetable Science, Dr. Y. S. Parmar University of Horticulture and Forestry, Nauni, Solan.

Kingsley O (2015) Studies on genetic variability in agronomic and fruit quality traits among some tomato (Solanum lycopersicum L.) genotypes, M.Sc. Thesis, University of Ghana, Ghana

Kumar Dharminder, Kumar Rajeev, Kumar Sandeep, Bhardwaj M L, Thakur M C, Kumar Ramesh, Thakur K S, Dogra B S, Vikram Amit, Thakur Ashok and Kumar P (2013) Genetic variability, correlation and path coefficient analysis in tomato. Int. J. Veg. Sci. 19: 313-23.

Kumar M S, Pal A K, Singh A K, Sati K and Kumar D (2013) Studies on genetic parameters to improve the genetic architecture of tomato (Solanum lycopersicum L.). Int. J. App. Bio. Pharm. Tech. 4:234-37.

Kumar N (2014) Studies on genetic variability in tomato (Solanum lycopersicum L.) genotypes for different horticultural traits, M.Sc. Thesis, Department of Vegetable Science, Dr. Y. S. Parmar University of Horticulture and Forestry, Nauni, Solan.

Kumar V, Nandan R, Srivastava K, Sharma S K, Kumar R and Kumar A (2012)
Genetic parameters and correlation study for yield and quality traits in tomato. The Asian J. Hort. 7:454-59.

Manna Madhurina and Paul Amitava (2012) Studies on genetic variability and characters association of fruit quality parameters in tomato. HortFlora Res. Spect. 1: 110-16.

Meena O P and Bahadur V (2014) Assessment of genetic variability, heritability and genetic advance among tomato (Solanum lycopersicum L.) germplasm. The Bioscan 9:1619-23.

Mehta N and Asati B S (2008) Genetic relationship of growth and development traits with fruit yield in tomato (Lycopersicon esculentum Mill.). Karnataka J. Agri. Sci. 21:9296.

Mohamed S M, Ali E E and Mohamed T Y (2012) Study of heritability and genetic variability among different plant and fruit characters of tomato (Solanum lycopersicum L.). Int. J. Scient. Tech. Res. 1:55-58.

Patel S A, Kshirsagar D B, Attar A V and Bhalekar M N (2013) Study on genetic variability, heritability and genetic advance in tomato. Int. J. Pl. Sci. 8:4547.

Prashanth S J, Jaiprakashnarayan R P, Mulge $\mathrm{R}$ and Madalageri M B (2008) Correlation and path analysis in tomato (Lycopersicon esculentum Mill.). The Asian J. Hort. 3:403-08.

Premalakshmi V, Kumar $\mathrm{S} \quad \mathrm{R}$ and $\mathrm{T}$ Arumugam (2014) Evaluation and genetic studies in tomato genotypes. Trend. Biosci. 7: 1407-10.

Rahaman S, Lakshman S S and Maitra N J (2012) Genetic variability and heritability studies in tomato (Lycopersicon esculentum Mill.). Int. J. Pl. Sci. 7:58-62.

Rai A K, Vikram A and Pandav A (2016) Genetic variability studies in tomato 
(Solanum lycopersicum L.) for yield and quality traits. Int. J. Agri., Env. Biotech. 9:739-44.

Reddy B R, Begum H, Sunil N and Reddy T M (2013) Genetic divergence studies in exotic collections of tomato (Solanum lycopersicum L.). Int. J. Agri. Sci. 9(2): 588-92.

Roy S K and Choudhary B (1972) Studies on physio-chemical characteristics of few varieties in relation to processing. $\mathrm{J}$. Food Sci. Tech. 9: 151-53

Sharma A K and Jaipaul (2014) Variability and correlation studies in diallel cross of tomato (Solanum lycopersicum L.). J. Hill Agri. 5:168-70.

Sharma J, Singh K A and Tiwari S P (2010) Selection parameters for productive plant type in tomato (Lycopersicon esculentum Mill.). J. Hill Agri. 1:5255.
Shashikanth B N, Hosamani R M and Patil B (2010) Genetic variability in tomato (Solanum lycopersicum Mill.). Karnataka J. Agri. Sci. 23:536-37.

Singh N, Ram C N, Deo C, Yadav G C and Singh D P (2015) Genetic variability, heritability and genetic advance in tomato (Solanum lycopersicum L.). Pl. Archives 15:705-09.

Singh Shashank Shekhar and Singh Devi (2019) Study of genetic variability of yield and its contributing characters in tomato (Solanum lycopersicum L.) under polyhouse condition. J. Pharm. Phytoch. 8(4): 2694-2697

Singh V, Naseeruddin K H and Rana D K (2014) Genetic variability of tomato genotypes for yield and other horticultural traits. J. Hill Agri. 5:18689.

\section{How to cite this article:}

Santosh Kumari and Sumit Patil. 2021. Assessment of Genetic Variability, Heritability and Genetic Advance in Tomato. Int.J.Curr.Microbiol.App.Sci. 10(12): 322-333.

doi: https://doi.org/10.20546/ijcmas.2021.1012.038 